DOI: 10.12797/Politeja.12.2015.37.03

Vincent DUJARDIN

Catholic University of Louvain (UCL, Belgium)

vincent.dujardin@uclouvain.be

\title{
BELGIUM WRESTLES WITH ITS IDENTITY(IES)
}

\section{A TEST LAB FOR EUROPE?}

ABSTRACT In this paper the author reconsiders the approach taken by Belgian politicians, working to promote European integration, vis-à-vis the question of European identity, roots and values, as well as their attitude towards European political objectives. We compare these views with those of French authors or politicians. Finally, we examine the current issues surrounding Belgian identity, caught between the French-speaking community and the increasingly strong Flemish identity. By way of a conclusion, I shall try to show how Belgium, with its identity-related issues, is sometimes presented as a 'test lab for Europe', as it was in the past, in completely different contexts, in 1921 at the time of the BLEU (BelgoLuxembourg Economic Union) and in 1944 with the founding of the Benelux union.

Keywords: Belgium, identity, European integration 
Since 2007, the future of Belgium, one of the founding countries of the European $\checkmark$ Union, has been under discussion. This is nothing new. For 182 years now, ever since the country came into being, questions have been asked as to its future - sometimes more so, sometimes less so over the years. In recent years, the questioning has become louder than usual. Is the case of Belgium, pulled apart by centrifugal forces, symptomatic of a phenomenon affecting Europe as a whole, since Europe is itself subject to the same forces?

In this paper, we consider the approach taken by Belgian politicians, working to promote European integration, vis-à-vis the question of European identity, roots and values, as well as their attitude towards European political objectives. We compare these views with those of French authors or politicians. Finally, we examine current issues surrounding Belgian identity, caught between the French-speaking community and the increasingly strong Flemish identity. By way of a conclusion, I shall try to show how Belgium, with its identity-related issues, is sometimes presented as a "test lab for Europe", as it was in the past, in completely different contexts, in 1921 at the time of the BLEU (Belgo-Luxembourg Economic Union) and in 1944 with the founding of the Benelux union.

\section{CENTRIFUGAL FORCES, IN BELGIUM AND EUROPE}

On 14 October 2007, referring to the governmental crisis, Alexandre Adler wrote, on the front page of Le Figaro, that after the forthcoming break-up of the Belgian State, Nicolas Sarkozy would be in charge of a greater France, soon to include Wallonia. To the question put in January 2007 by Francis Delperée, a member of the Belgian senate, in the Revue générale - 'Will There Be a Belgian War?'1 - Le Nouvel Observateur seemed to reply in its headlines of 6 September, speaking of 'The Belgian War' without a question mark. Similarly, the title of Newsweek on 24 September 2007 was 'Belgium's Separatist Crisis'.

In short, in the autumn of 2007, not a day went past without the international press questioning the future of Belgium. From Washington to Taipei, from Vienna to London, talk was of an imminent splitting-up of the country. Such thoughts, however, are not new. On $19^{\text {th }}$ January 1980 , while Belgium was celebrating its $150^{\text {th }}$ anniversary, The Economist already wrote that Belgium was the most unnatural country in Europe. It has neither a common language, nor natural frontiers, nor the tradition to give its people a sense of national identity. [...] Although Belgium is a small country $[\ldots]$ there is a risk that it will break up into two semi-independent states in this decade. [...] Fortunately, most Belgians are more interested in moules than in politics. In this regard, we have to mention that between 1978 and 1981, Belgium went through eight governments! And between 1965 and 1981, seven legislative elections took place in

F. Delperée, 'La guerre des Belges aura-t-elle lieu?', La Revue Générale, No. 1 (2007), p. 5. 
seventeen years' time. In June 1983, King Baudouin wrote to his father: The country seems to be more divided than ever. Yesterday, it was the Royal Question, today, national solidarity together with State's structures are questioned [...] The Prime Minister spares no pains to save and rebuild our country. Looking further back in history: didn't Bismarck already say in 1866: I believe Belgium will not be a viable State in the long run? Leopold I, the first King, himself wrote to his son in 1860 that there is no national feeling in Belgium.

In fact, until 1914, the legitimacy of the Belgian State had not been obvious abroad. But then, with the war, the Belgian national feeling is probably at its height although, at the same time, the first cracks occurred at this time with the emergence of the Flemish national feeling that had become, to a minor extent, anti-Belgian. In other words, for 185 years times have been difficult for Belgium with variable intensity depending on periods and contexts that I cannot picture here. But this remark should not lead to over-optimism. Borders are not unchangeable and everything can evolve. On $11^{\text {th }}$ March 1882, Ernest Renan claimed: Nations are not everlasting: they emerged, they will vanish.

This paper will not give a detailed history of these problems. I would nevertheless like to emphasise the quotation of 22 July 1966 from the French Ambassador to Brussels. Six days earlier, the same diplomat noted that: We must be very reserved in what we say, but must not remain indifferent to what amounts to a substantial erosion of our culture and our influence on our very doorstep. [...] We can do nothing, but I still wonder whether, if we were to think in the near future of making certain proposals to give new impetus to the Common Market, we could not include a suggestion on a particular status for the headquarters of the institutions, a sort of neutral status for the area surrounding the European institutions, to encourage the efforts being made by the partisan political groupings to maintain balance within Belgium, with a capital city free from language-related quarrels. [...] In any case, if we do not do this now, we can one day use this argument to request a transfer, if the situation in Brussels were at any time to become unpleasant or contrary to our interests.

This question, then, should be seen in the context of the battle to house the headquarters of the European institutions (a battle which is still not quite over, particularly between Strasbourg and Brussels), which, even at that stage, meant that the situation of Belgium was closely bound up with European plans for further integration. On 31 October 1962, Pierre Harmel, the future Belgian Prime Minister, declared to Parliament that a new agreement on Belgian unity had to be found "to last another twenty or so years", until Europe became a political force in its own right. Belgian federalism is first of all a distancing federalism that did not introduce any centripetal strength. As a consequence, collaboration and cooperation agreements between the different power levels require the use of positive law. Those agreements, which are therefore not spontaneously reached, come out of negotiation strategies.

Belgium, however, is not the only European country having to deal with centrifugal forces. The same is true for the European Union itself. It is, then, helpful to consider the question of Belgian identity together with the identity of Europe as a whole. 


\section{BELGIAN IDENTITY(IES) AND THE ROOTS OF EUROPE}

The question of Belgian identity(ies) is linked to the issue of European identity and therefore of European roots, since identity is made up of an accumulated series of legacies. How, then, can it be defined? ${ }^{2}$ Cultural identity is based on an interpretation of the history of the community (in all its aspects: its physical, institutional and social environment) as a system of norms and values. These codes, rules and norms change gradually over time. Collective cultural identities, like individual identities, are not static, not permanent attributes of a group or society (as culturalists might suggest); rather, they are constantly torn between continuity and change, and alter as they integrate, abandon and take over new ideas. Identity, then, is not just inherited from the past, since the image of the past is integrated into the present, and the way in which it is used changes as society evolves.

Identity is multi-faceted and interactive, in the same way as allegiances, and a little like the multiple layers of an onion. It is entirely possible to feel at the same time Parisian, French and European, or Flemish, Belgian and European. How, though, can we define a European identity?

European identity, firstly, cannot be defined in terms of borders. This becomes clear when we consider the eastern border of Europe. The French President Nicolas Sarkozy declared in Le Monde, on 12 May 2009, that if Europe has no borders, is has no strength, no identity, no values. He also made the following statement: At school I learnt that Turkey was a country in Asia. That means it is not part of Europe. If Turkey joins the European Union, why not Morocco? Is he right?

Europe, it is true, has certain geographical characteristics - particularly hydrographic features and the closeness of much of the continent to the sea - which have favoured both maritime trade and the development of maritime powers. Analysis will show, however, that European identity cannot be defined by borders. If we say that any area east of the Bosphorus is no longer Europe, then what of Cyprus, which lies east of the Bosphorus and is a member of the EU? General de Gaulle and others have often referred to the Urals as a possible eastern border, but the Urals are just not a very high range of mountains, the highest of which, right at the Northern end of the range, reaches only 1,894 metres. The Ural Mountains have never been a real barrier to population movements. Indeed, Hannibal's elephants crossed the Alps as early as $200 \mathrm{BC}$. This range can be used as a conventional boundary, but not as a definitive boundary to Europe, which is not clearly delineated, particularly to the East. Thus the EU has 28 Member States, while UEFA (the Union of European Football Associations) has 53 members, including Turkey. The Bologna process, aiming to reform university education in the EU, has 47 member countries, including Turkey. Finally, the European Broadcasting Union represents national broadcasters in 56 countries, including Azerbaijan. Borders, then, are not always the criterion used to determine what is European and what is not.

2 B. Coulie in B. Coulie, V. Dujardin, Fondements de l'intégration européenne. Histoire, géographie, culture, structures, Louvain-la-Neuve 2012. 
The countries of the EU have come together mainly as a result of shared civilisation, culture, ${ }^{3}$ roots and values. For French historian Charles-Olivier Carbonell, Europe can be defined as that area which has taken on the dominant features of European civilisation: Europe ends, he says, where the dominant features of its civilisation, those of historical and territorial importance, can no longer be seen or are transitory in terms of time or space. One example is the prevalence of towns and cities, a marked characteristic of Europe. The average distance between towns of more than 10,000 inhabitants is 10 to $20 \mathrm{~km} .{ }^{4}$ In North America, this distance is 20 to $80 \mathrm{~km}$, and in tropical Africa it is $200 \mathrm{~km}$. Another important factor, as recalled by a former French minister, is that of values:

Are there such things as European values? Do Europeans carry with them a set of shared values, which are the basis for European identity and can provide guidelines for the "European project"? The answer to that question will determine the choices facing Europe today. For if we feel that Europeans are, ultimately, too different in their outlooks, that they share only rather vague and very universal values; if we see Europe as just a multiplicity of disparate entities which have managed to adopt a legal framework to put some order into their mutual relations, then clearly there is no case for developing Europe as a political entity. ${ }^{5}$

This is still a very topical issue, at a time when the sovereign debt crisis facing many countries and the euro zone as a whole is calling into question the whole "European project". Last August, Jacques Delors, the French former President of the Commission, described Europe, in what were probably somewhat alarmist terms in the circumstances, as on the edge of a precipice. What were the origins, then of the idea of "Europe", or of the European integration movement? What was the driving force behind the "European project"? Victor Hugo declared that: the events in Serbia show the need for a United States of Europe. May disunited governments be succeeded by united peoples. Let us put an end to murderous empires. Let us silence fanatism and despotism... no more war, no more massacres, no more carnage; free thought, free trade; brotherly love... The atrocities committed in Serbia show without a doubt that Europe needs a European nationality, a united government, wide-scale fraternal arbitration, democracy at peace with itself... in a word, a United States of Europe. There lies the goal, the haven. These are not the words of Jacques Delors in 1994, referring to the war in former Yugoslavia, but rather those of Victor Hugo in 1876 - the year of the bloody war between Turks and Serbs. One of the driving forces behind European integration is thus the desire for peace. The words "peace" or "peaceful" figure five times in the brief Schuman Declaration of 9 May 1950 - the founding document of the ECSC, the forerunner of the EU. Clearly we should not be naïve: there were other objectives also, particularly economic objectives. Nevertheless, peace was an important factor.

3 There are many ways to define the word "culture". For our purposes, it can be seen as the set of types of behaviour and representation reflecting, for a given group or society, the way in which the majority of its members relate to the world. Every culture acts as a coordinated system of (founding) values, (organisational) norms and (declaratory) rules - C. Javeau, Masse et impuissance. Le désarroi des universités, Brussels 1998, p. 45 (Quartier Libre).

$4 \quad$ B. Coulie in B. Coulie, V. Dujardin, Fondements...

5 Paris, Senate, 14/10/2005 [jest to najwyraźniej wypowiedź spisana z nagrania telewizyjneg, stąd brak możliwości podania bardziej szczgółowego zapisu] 
The preamble to the 1957 EEC Treaty, drafted by a Frenchman, contains the same objectives: to preserve and strengthen peace and liberty, and to lay the foundations of an ever closer union among the peoples of Europe. This allusion to an ever closer union among the peoples of Europe brings us back to the question of European culture, of common European roots helping the cause of unity, which I shall now examine.

The word "Europe", which itself comes from Greek Antiquity, is used by Herodotus to denote "civilisation". Since then, this civilisation has developed on the basis of three cultural legacies. The French writer Paul Valéry described Europe as the place where Roman influences on administration, Greek influences on thought and Christian influences on spiritual life can all be felt. These words are true but do not tell the whole story, since European identity and culture have been continuously evolving since Antiquity. Christianity, moreover, spread through Eastern Europe later than through Western Europe, although it played quite a key role in 1989 in overthrowing the post-Yalta world order. In Belgium, religious issues were also important to the founding of the Belgian State in 1830, since the Belgian population, the vast majority of whom were at the time Catholic, sought religious freedom from the occupying Dutch Protestant power. The great historian Salvador de Madariaga took a similar view to Valéry, describing Europe as born of Socrates and Jesus Christ, and proclaiming that there have always been men, but man began with Jesus. In 1973, on receiving the Charlemagne prize, he developed this theme further: Socrates taught Europe to respect freedom of thought, and Christ taught her to respect the human person. We can thus state clearly that nothing which poisons Socrates or crucifies Christ can be described as truly European. Who can deny that in the course of European history many crimes have been perpetrated against both Socrates and Christ? Ultimately, though, Europe has always condemned such crimes as scandalous mistakes. And we still, more than ever, believe that freedom of thought and respect for the human person are consubstantial to Europe, so that Europe ends at that place where one of these commandments is broken.

The Belgian Foreign Affairs Minister, Paul-Henri Spaak, one of the key players behind Belgium's signing of the Treaty of Rome in 1957, made a similar point before Parliament in May 1957, several weeks after the signing of the EEC and Euratom treaties: My Socialist friends think that I am teasing them when I speak of Christian civilisation, but let me explain once more what I mean [...] I believe that there are incontestable historical facts, and I am saying this as someone, as I said before, who is not a Catholic, not even a believer, and does not boast about the fact. But I have to acknowledge that our Western civilisation came into being shortly before the time of Christ, in Greece, and was strengthened by the teachings of Christ, and is based on something essential, a principle which, if we follow it, has countless consequences. Our Christian civilisation is tailored to buman needs, because it is centred around the vital idea of respect for the human person. It is on this point, and on many others too, that I agree with the Christians. Undeniably, this teaching of Christ has, down through the centuries, drawn us inexorably closer together. ${ }^{6}$ Spaak, then, refers to Greek and Christian roots. To my mind he overlooks the clear Roman roots of our culture. It was through Rome, firstly, that we inherited Greek culture, as well as

\footnotetext{
Annales parlementaires. Chambre, October 1962, p. 27.
} 
towns and cities, administration, law, highly political Roman art, etc. This period was followed by the invasions or large-scale migrations which continued till the tenth century. Later, other factors and events also marked European culture, such as the Age of Enlightenment. The relatively uniform development of Western and Central Europe, moreover, and the establishment of a fairly dense tissue of towns and cities in the Middle Ages, followed by industrialisation in the nineteenth century, all made for a convergence of ideas, whereas the emergence of nation states, also during the nineteenth century, accentuated differences.

The principle, then, shared by Spaak, one of the leading lights behind European integration, with Christianity, is the universal respect for the human person. Christianity was at the origins of the concept of human rights, and inspired the English colonists wishing to free themselves from the British crown who drew up the Virginia Declaration of Rights in 1776. Like Christian thought, the 1789 declaration was intended as a universal text, and was thus a source of inspiration for the authors of the two most significant documents of the twentieth century: the Universal Declaration (without a legal value) of Human Rights, adopted by the UN Assembly in 1948, and which affirms the dignity, freedom and equality of all human beings endowed with reason and conscience, and the 1950 European Convention (with legal value) on Human Rights.

These are the origins of the pursuit of the common good which also lies at the heart of European integration. There are close links between Europe and the United States, for demographic and historical reasons, if nothing else. Nevertheless, there are also clear cultural differences between these two world regions. The United States shares in our European heritage, yet, as is highlighted by A. Stephanou, an even greater value is placed on human life in Europe than on the other side of the Atlantic. The European welfare state reflects the idea of a common destiny, whereas the American model reflects the principle of individual responsibility.

The American Joseph E. Stiglitz, recipient of the Nobel Prize for Economics, spoke in Brussels in 2007 at an event organised to celebrate 50 years of the Treaties of Rome, on what distinguishes Europe from the rest of the world, and what, in certain points, distinguishes it also from the United States. He referred to democracy, social justice and solidarity, respect for the dignity of the human person, the exercise of public authority in the pursuit of the common good, and the legacy of the Enlightenment, which encourages a critical approach. The preamble to the 2004 Treaty establishing a Constitution for Europe lists the five values mentioned by Stiglitz ${ }^{7}$. European identity links the individual to society.

The preamble refers to the cultural, religious and humanist inheritance of Europe, from which have developed the universal values of the inviolable and inalienable rights of the human person, freedom, democracy, equality and the rule of law. It also affirms respect for human rights and fundamental freedoms and of the rule of law, as well as solidarity between their peoples while respecting their history, their culture and their traditions. The objective of the Union is also still to promote peace and to continue the process of creating an ever closer union among the peoples of Europe, in which decisions are taken as closely as possible to the citizen in accordance with the principle of solidarity - B. Coulie in B. Coulie, V. Dujardin, Fondements... 
Two of the points emphasised, then, are social justice and solidarity. These principles, however, are today being questioned in Belgium, as well as in the EU, as I will explore in the last section of this contribution.

\section{BELGIUM 2012 - A TEST LABORATORY FOR EUROPE?}

Is Belgium currently acting as a sort of "test lab for Europe"? As Belgium tries to strike a new balance between solidarity and subsidiarity, the issues it is coming up against are of relevance not just to the country itself, but to Europe as a whole. This search for a new equilibrium can be seen in connection with the debt crises of various countries, and with the particular case of Greece. It can be seen in Spain, Italy, the United Kingdom, even in France, where certain pro-autonomy tendencies are gaining ground. It was not by chance that Spain, Cyprus and, therefore, Greece were among the five European States not to acknowledge Kosovo. It was important not to give ideas to the Catalans or the Basques. Belgium is not alone: other European countries also have problems of identity and centrifugal forces to deal with. The Belgian State has to respect regional and local identities, in the same way that the EU respects the identities of its Member States, the key thing being to strike a difficult balance between European and regional power centres. The real balance that needs to be struck is between the overly-ambitious project of a United States of Europe, and the idea of a Europe of the nations, which, with 28 countries, would be ineffective, although, of course, individual States still play a substantial role, particularly within the European Council.

Our democracies, moreover, came into being in a context of nation states, each with its own view of the history of democracy.

In addition, the development of Europe has been based on a partnership between France and Germany, which has often been the driving force behind further integration. These two countries have cultural roots which are sometimes identical, as we have seen, but also their own identities. They are two nation states. France was firstly a state before it was a nation, so it tends to prefer the intergovernmental method in order to assert its identity. Germany was a nation before becoming a federal state, which makes it more inclined to accept the Community method, for reasons of effectiveness. Rivalry between these two countries also lies at the heart of the European project, which was originally intended to create a sound foundation for reconciliation between France and Germany, at a time when only Western Europe was in a position to move towards greater integration.

Belgium, with its Flemish and French-speakers (as well as several tens of thousands of German-speakers) stands at the crossroads of Latin and Germanic cultures: hence its identity problems. It was therefore, though, right from the outset, an obvious candidate for the European integration project.

Since autumn 2011, with the Eurozone and debt crises, we have seen a powerful comeback of the Franco-German partnership, dictating the measures to be taken, as well as a questioning of the principle of solidarity and the strengthening of national and 
regionalist identities. All of this is rooted in the relatively distant past. In 2005, we saw how the mere mention of a European flag or anthem in the constitutional treaty could cause difficulties for some states, who saw them as too strong a means of creating identity, backed up by the existence of the single currency. This was the case for the Netherlands, the United Kingdom and the Czech Republic. Clearly, if the European project is to survive, it must overcome these antagonistic feelings. The European Union is both one and diverse, with its 24 official languages for 28 Member States. Identity is something which is constantly being developed through a clash of similarities and differences, but it will require the use of many languages. ${ }^{8}$

Europe has often been defined in opposition to a common danger. Today Europe must define itself in its own right.' If Europe cannot be defined by its borders, then its values, springing from common roots, from a shared cultural inheritance which leaves room for differences, can draw countries together, if, and only if, there is the political desire to achieve European unification. This desire could spring solely from a wish for greater influence on the globalised world stage, in a world in which demographic developments are to the detriment of the countries of "old Europe". The choice facing Europe could be to act as one or to fade from the scene.

Even in the near future, Europe will only survive if its member nations continue to hold strongly to and to promote the human values passed down through its civilisation. Decadence, said Denis de Rougemont, only occurs when people stop asking "what shall we do?" and instead ask "whatever will happen?"

\section{BIBLIOGRAPHY}

Annales parlementaires. Chambre, October 1962.

Bréhier T., Le Monde littéraire, 30 April 1999. Critique of Les racines de lidentité européenne by G.-F. Dumont, Paris 1999.

Coulie B. in B. Coulie, V. Dujardin, Fondements de l'intégration européenne. Histoire, géographie, culture, structures, Louvain-la-Neuve 2012.

Delperée F., 'La guerre des Belges aura-t-elle lieu?', La Revue Générale, No. 1 (2007).

Dumont G.-F., Les racines de l'identité européenne, Paris 1999.

Javeau C., Masse et impuissance. Le désarroi des universités, Brussels 1998 (Quartier Libre).

8 G.-F. Dumont, Les racines de l'identité européenne, Paris 1999, p. 373.

9 T. Bréhier, Le Monde littéraire, 30 April 1999. Critique of Les racines de l'identité européenne by G.-F. Dumont.

Vincent DUJARDIN is President of the Institute for european studies and professor at the Catholic University of Louvain (UCL, Belgium). He is also Professor visitor at the University of Szeged (Hungary). 